\title{
Risk factors for alloimmunization by patients with sickle cell disease
}

M. Murao ${ }^{1}$
and M.B. Viana $^{2}$

\author{
Correspondence \\ M.B. Viana \\ Departamento de Pediatria \\ Faculdade de Medicina, UFMG \\ Av. Alfredo Balena, 190 \\ 30130-100 Belo Horizonte, MG \\ Brasil \\ Fax: +55-31-3248-9664 \\ E-mail: vianamb@medicina.ufmg.br \\ M.B. Viana is the recipient of a CNPq \\ fellowship.
}

Received October 29, 2003 Accepted December 9, 2004 $\ldots \ldots \ldots \ldots \ldots \ldots \ldots$
${ }^{1}$ Fundação Hemominas, and ${ }^{2}$ Departamento de Pediatria, Serviço de Hematologia, Hospital das Clínicas, Universidade Federal de Minas Gerais, Belo Horizonte, MG, Brasil

\begin{abstract}
Blood transfusion in patients with sickle cell disease (SCD) is limited by the development of alloantibodies to erythrocytes. In the present study, the frequency and risk factors for alloimmunization were determined. Transfusion records and medical charts of 828 SCD patients who had been transfused and followed at the Belo Horizonte Blood Center, Belo Horizonte, MG, Brazil, were retrospectively reviewed. Alloimmunization frequency was $9.9 \%$ (95\% CI: 7.9 to $11.9 \%$ ) and 125 alloantibodies were detected, $79 \%$ of which belonged to the Rhesus and Kell systems. Female patients developed alloimmunization more frequently $(\mathrm{P}=0.03)$. The median age of the alloimmunized group was 23.3 years, compared to 14.6 years for the non-alloimmunized group $(\mathrm{P}<0.0001)$. Multivariate analyses were applied to the data for 608 hemoglobin (Hb) SS or SC patients whose number of transfusions was recorded accurately. Number of transfusions $(\mathrm{P}=0.00006)$, older age $(\mathrm{P}=0.056)$ and $\mathrm{Hb}$ SC $(P=0.02)$ showed independent statistical associations with alloimmunization. Hb SC patients older than 14 years faced a 2.8fold higher (95\% CI: 1.3 to 6.0) risk of alloimmunization than Hb SS patients. Female $\mathrm{Hb}$ SC patients had the highest risk of developing alloantibodies. In patients younger than 14 years, only the number of transfusions was significant. We conclude that an increased risk of alloimmunization was associated with older patients with $\mathrm{Hb}$ SC, specially females, even after adjustments were made for the number of transfusions received, the most significant variable.
\end{abstract}

Key words

- Sickle cell disease

- Red cell alloimmunization

- Blood cell transfusion

- Transfusion reactions

\section{Introduction}

Sickle cell anemia is one of the most common hereditary diseases in Brazil (1). Although its true incidence is unknown, it is estimated that 2 to $8 \%$ of the Brazilian population harbor the sickle cell trait, according to the intensity of the migratory flow of the black population in each region. It is estimated that more than two million Brazilians carry the sickle cell trait and more than 8,000 present the homozygous hemoglobin $(\mathrm{Hb})$ SS disease (1).

Due to the high morbidity of sickle cell disease (SCD) and limitations of the therapeutic options, many patients receive transfusions for the various complications that ensue. Hence, transfusion therapy has been widely used, integrating the treatment ever since the 1930's (2). With the recognition of the efficacy of transfusion therapy for the prophylaxis and treatment of some SCD 
complications, the number of patients receiving intermittent transfusion continues to increase (2-7).

One of the main complications of red blood cell (RBC) transfusion is the development of alloimmunization to RBC antigens, with a frequency ranging from 2.6 to $76 \%$ in several studies $(3,5,8-17)$.

Alloimmunization may limit the availability of compatible blood for future transfusions and can contribute to perinatal morbidity due to hemolytic disease in the newborn $(2,6,9,18)$. The probability of the occurrence of alloimmunization is related to several factors such as age, number of transfusions, phenotypic differences between the donor and the receptor, and genetic factors related to the antigenic response $(2,3,5,8$ 15,19-21).

The antigens most frequently involved include the Rhesus, Kell, Kidd, Duffy, Lewis, and MNS systems $(3,8-15,20,22)$. The objective of the present study was to determine the frequency of alloimmunization to RBC antigens in patients with SCD who had been transfused at a large Brazilian Blood Center located in Belo Horizonte, MG, Brazil, and the possible association between alloimmunization and the number of transfusions, age, gender, and $\mathrm{Hb}$ phenotype.

\section{Patients and Methods}

\section{Patients}

All 1,780 patients with SCD (Hb SS, Hb $\mathrm{SC}, \mathrm{Hb} \mathrm{S} \beta^{+}$-thal, $\mathrm{Hb} \mathrm{SD}$ ) enrolled at the Blood Center of Belo Horizonte up to December 31st, 2000 were investigated. Deceased patients, those who did not maintain periodic control in the Service, and those for whom accurate data about previous transfusions were not available before they were admitted to the Blood Center were excluded. Of the remaining 1,544 patients, 645 (41.8\%) had not been submitted to blood transfusion. Screening tests for antibodies after last trans- fusion were not performed in 71 of the 899 patients selected for the study who did not show up on recall, resulting in a loss of $7.9 \%$ patients. The group analyzed in the present study comprised 828 patients phenotypically distributed as follows: $81.8 \%$ with $\mathrm{Hb}$ SS or $\mathrm{S} \beta^{0}$-thal, $15.9 \%$ with $\mathrm{Hb} \mathrm{SC}, 2.2 \%$ with $\mathrm{Hb} \mathrm{S}^{+}$ thal, and $0.1 \%$ with $\mathrm{Hb}$ SD. There were 405 $(48.9 \%)$ males and $423(51.1 \%)$ females. Median age was 18.4 years (1.2 to 78.8 years). Median age on the day of antibody screening was 15.4 years ( 0.5 to 76.1 years).

The diagnosis of SCD was confirmed by standard $\mathrm{Hb}$ electrophoresis, isoelectric focusing, determination of $\mathrm{Hb} \mathrm{A}_{2}$ and $\mathrm{HbF}$, and family studies, when necessary.

\section{Data collection}

The records of all patients were reviewed. The number of transfusions was obtained from the transfusion history recorded in medical charts, including those before admission, from information given by the patient or relative, and from the Blood Center form for transfusion prescription. For 16 patients on a chronic transfusion regimen, only transfusions administered before the study cut-off date of April 31st, 2001 were considered. Information from patients or relatives regarding the number of transfusions received was considered unreliable in 208 cases $(25.1 \%)$. It was thus possible to determine the number of blood transfusions for 620 (74.9\%) patients. Of these, 297 were females and 150 were 14 years or older. For 76 , obstetric history was not available in the medical records; for the remaining ones, 18 had never been pregnant and 56 had at least one pregnancy. The high percentage of missing data precluded valid statistical tests for this variable.

\section{Laboratory protocol}

Antibody screening. Detection of alloantibodies was performed in fresh blood 
samples using the indirect human antiglobulin test (indirect Coombs) in low-ionic-strength solution (LISS) by the tube method up to July 1991 and thereafter by the column agglutination method, employing phenotyped "O" RBC. For the column agglutination method, the gel centrifugation technique was used (DiaMed AG, Cressier sur Morat, Switzerland). All patients were screened before any transfusion. Starting in 1995, every sickle cell patient registered or scheduled for a new appointment at Hemominas Foundation had his/her RBC immunophenotyped and serum screened for alloantibodies.

Antibody identification. Antibody specificity was determined with a standard panel of red cells reacting to known antigens using column agglutination and gel centrifugation (ID-Diapanel and ID-DiaPanel-P, DiaMed AG). The indirect Coombs test using LISS as a potentiator at $37^{\circ} \mathrm{C}$, the enzymatic papaintreated $\mathrm{RBC}$ test at $37^{\circ} \mathrm{C}$ and the indirect Coombs test at $4^{\circ} \mathrm{C}$ were always included. A positive serum that became negative after incubation with 2-mercaptoethanol was considered evidence for an IgM subtype. When necessary, the monospecific direct Coombs test, adsorption and elution of antibodies, and the indirect Coombs test with selected RBC (specific antigens) were also employed. Natural antibodies were considered those of the IgM type and of low titer.

\section{Statistical analysis}

For univariate analysis of the association between alloimmunization and age at antibody screening, gender, number of transfusions and type of hemoglobinopathy, the chisquare test was used for discrete variables and the Mann-Whitney test was used for continuous variables with non-Gaussian distribution. Multivariate logistic regression analysis was done with the MINITAB software, version 13.20 (State College, PA, USA). Alloimmunization (positive or negative) was the dependent variable and the remaining explanatory variables were the covariables. The continuous variables age and number of transfusions, given their non-Gaussian distribution, were included in the model after being transformed into ordinal variables, classified into ranks. Only variables with $\mathrm{P}<0.1$ were kept in the final multivariate model.

The study was approved by the Ethics Research Committee of Hemominas (resolution 057/2000).

\section{Results}

IgG alloantibodies were detected in 82 of the 828 patients who received transfusions (9.9\%; $95 \%$ confidence interval, $\mathrm{CI}=7.9$ to $11.9 \%$ ). Of these 82 patients, 29 tested positive before their first blood transfusion at Hemominas. A hundred and twenty-five IgG alloantibodies were detected. In one patient the antibody identification was not performed. Twenty-nine patients $(35.4 \%)$ presented two or more alloantibodies; the presence of an autoantibody of the IgG class was also detected in $14(17.1 \%)$. Cold antibodies detected in 3 patients were not included in the study. The specificities and frequencies of the alloantibodies are shown in Table 1. They did not differ significantly when patients who tested positive before first transfusion at Hemominas were compared with those who were negative. Of the 124 alloantibodies identified, $69.4 \%$ were directed against antigens of the Rhesus group and $9.7 \%$ were directed against antigens of the Kell group, corresponding to $79.1 \%$ of the alloantibodies detected.

Of the 82 alloimmunized patients, $37.8 \%$ were males and $62.2 \%$ females $(\mathrm{P}=0.03)$; $78 \%$ were $\mathrm{Hb} \mathrm{SS}$ or $\mathrm{S}^{0}$-thal, $20.7 \% \mathrm{Hb} \mathrm{SC}$ and $1.2 \% \mathrm{Hb} \mathrm{SB}^{+}$-thal patients. The median age at antibody screening was 23.3 years in the alloimmunized group and 14.6 years in the non-alloimmunized group $(\mathrm{P}<0.0001$; Table 2).

To analyze the risk of alloimmunization dependent on the variables gender, age, type 
of hemoglobinopathy, and number of transfusions, 620/828 patients whose number of transfusions was known were separated. The difference in the frequency of alloimmunization between this group and the group whose number of transfusions was unknown was not statistically significant $(P=0.24)$. The frequency of alloimmunization found in the group of patients with a known number of transfusion was $9.2 \%(57 / 620)$ with a $95 \%$ CI of 6.9 to $11.5 \%$. Median age was 21.5 years for alloimmunized patients and 11.8 years for non-alloimmunized patients $(\mathrm{P}$ $=0.0001)$. Despite the higher frequency in females $(11.1 \%$ as opposed to $7.4 \%$ for males), this difference was not statistically significant $(\mathrm{P}=0.11)$. Median age was 25.3 years for the alloimmunized female patients and 15.1 years for the male patients. Alloimmunization was more frequent in $\mathrm{Hb} \mathrm{SC}$ patients than in $\mathrm{Hb}$ SS patients (14 vs 8.1\%; $\mathrm{P}=0.048)$. Alloimmunized patients received a median number of 7 blood transfusions, as opposed to 3 transfusions for non-alloimmunized patients $(\mathrm{P}<0.0001$, Figure 1$)$. Table 3 lists the number of transfusions by age group and alloimmunization.

After multivariate adjustment $(\mathrm{N}=608$, since 11 patients with $\mathrm{Hb} \mathrm{S}^{+}{ }^{+}$-thal and one with $\mathrm{Hb} \mathrm{SD}$ were excluded from this analy-

\begin{tabular}{|c|c|c|c|c|c|c|c|}
\hline \multirow[t]{3}{*}{ RBC antibody specificity } & \multicolumn{3}{|c|}{ Single } & \multicolumn{3}{|c|}{ Multiple } & \multirow[t]{3}{*}{ Total (\%) } \\
\hline & \multirow{2}{*}{$\frac{\text { Male }}{\text { All }}$} & \multicolumn{2}{|c|}{ Female } & \multirow{2}{*}{$\frac{\text { Male }}{\text { All }}$} & \multicolumn{2}{|c|}{ Female } & \\
\hline & & $<14$ years & $>14$ years & & $<14$ years & $>14$ years & \\
\hline Anti-C & 2 & 1 & 2 & 7 & 1 & 10 & $23(18.5)$ \\
\hline Anti-D & 1 & 1 & 2 & 5 & - & 2 & 11 (8.9) \\
\hline Anti-E & 10 & 2 & 12 & 3 & 2 & 12 & $41(33.1)$ \\
\hline Anti-c & 1 & - & 3 & 1 & - & 4 & $9(7.3)$ \\
\hline Anti-e & 1 & 1 & - & - & - & - & $2(1.6)$ \\
\hline Anti-K & 2 & - & 2 & 2 & 1 & 5 & $12(9.7)$ \\
\hline Anti-Fya & 2 & - & - & 2 & - & 3 & $7(5.6)$ \\
\hline Anti-Le ${ }^{a}$ & 1 & - & - & - & - & 2 & $3(2.4)$ \\
\hline Anti-Jk ${ }^{a}$ & 1 & - & 3 & 1 & - & - & $5(4.0)$ \\
\hline Anti-Jk ${ }^{b}$ & - & - & - & - & - & 1 & $1(0.8)$ \\
\hline Anti-M & - & - & 1 & 1 & - & 2 & $4(3.2)$ \\
\hline Anti-S & - & - & 1 & 1 & - & 3 & $5(4.0)$ \\
\hline Anti-P & - & - & - & 1 & - & - & $1(0.8)$ \\
\hline Total & 21 & 5 & 26 & 24 & 4 & 44 & $124(100)$ \\
\hline
\end{tabular}

In one patient, antibody identification was not performed. RBC $=$ red blood cell.

Table 2. Distribution of 828 patients with sickle cell disease according to median age, hemoglobin ( $\mathrm{Hb})$ phenotype, and gender.

\begin{tabular}{|c|c|c|c|c|c|c|}
\hline \multirow[t]{2}{*}{ Patients } & \multirow[t]{2}{*}{ Number } & \multirow{2}{*}{$\begin{array}{l}\text { Median age }{ }^{1} \\
\text { (range) }\end{array}$} & \multicolumn{2}{|c|}{ Type of $\mathrm{Hb}^{2}$} & \multicolumn{2}{|c|}{ Gender ${ }^{3}$} \\
\hline & & & $\mathrm{SS}^{*}$ & $S C / S \beta^{+}$-thal/SD & Male & Female \\
\hline Non-alloimmunized & 746 & 14.6 (0.5 to 76.1$)$ & 613 & 133 & 374 & 372 \\
\hline Alloimmunized & 82 & 23.3 (2.2 to 48.3 ) & 64 & 18 & 31 & 51 \\
\hline Total & 828 & 18.4 (1.2 to 78.8$)$ & 677 & 151 & 405 & 423 \\
\hline
\end{tabular}

${ }^{*}$ Included $\mathrm{S} \beta^{0}$-thal. ${ }^{1} \mathrm{P}<0.0001$ (Mann-Whitney test); ${ }^{2} \mathrm{P}=0.36$ (chi-square test); ${ }^{3} \mathrm{P}=0.03$ (chi-square test). 
sis), gender was not statistically significant $(\mathrm{P}=0.35)$. Explanatory variables that remained statistically significant for alloimmunization were: higher number of transfusions received $(\mathrm{P}=0.00006)$, older age $(\mathrm{P}=0.056)$ and SC compared with SS disease $(\mathrm{P}=$ 0.02 ).

Because obstetric history at the time of alloantibody detection was not available for almost $50 \%$ of females older than 14 years, separate analyses were performed for patients under or above this cut-off point. For those below 14 years, only the number of transfusions remained statistically significant in multivariate analysis $(\mathrm{P}=0.0001)$. For those above 14 years, number of transfusions $(\mathrm{P}=0.04)$ and type of SCD $(\mathrm{P}=$ $0.008)$ remained significant in multivariate analysis. These $\mathrm{Hb} \mathrm{SC}$ patients were at a 2.8fold higher risk of alloimmunization than SS patients (95\% CI $=1.3$ to 6.0 ). The median numbers of blood transfusions for $\mathrm{Hb} \mathrm{SC}$ and SS patients were 3 and 6, respectively (P $<0.0001)$. Male and female patients received the same median number of transfusions (5; $\mathrm{P}=0.87)$. The frequency of alloimmunization for patients younger or older than 14 years according to sex and type of SCD is presented in Table 4 . The frequency of alloimmunization was higher for $\mathrm{Hb} \mathrm{SS}$ children $(<14$ years old), although not statistically significant $(\mathrm{P}=0.24)$; no significant difference was observed between males and females. Hb SS children, however, received more blood transfusion than SC children: $12 \%$ of SS children received more than 15 transfusions whereas no SC child received this number of transfusions. A double positive gradient from males to females and from $\mathrm{Hb}$ SS to SC was observed for patients older than 14 years. The highest frequency was observed in $\mathrm{Hb} \mathrm{SC}$ female patients (12/46 = $26.1 \%)$.

\section{Discussion}

Of the 1,544 patients initially studied, 899

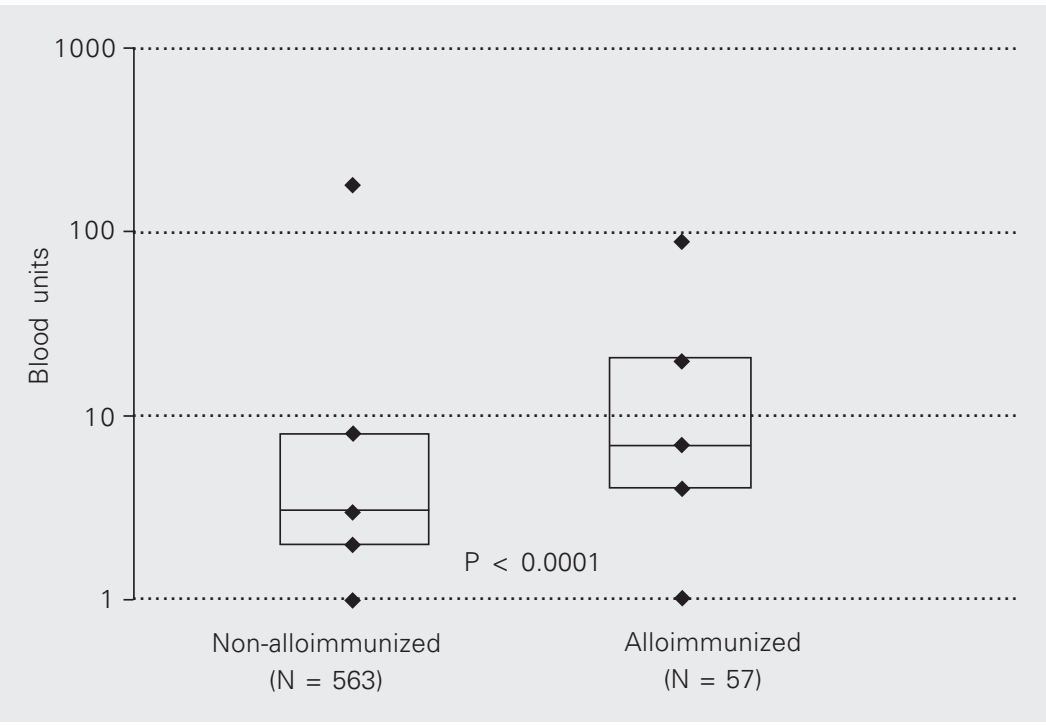

Figure 1. Number of transfusions received by alloimmunized and non-alloimmunized patients with sickle cell disease. Higher to lower, the points indicate maximum number, 75th percentile, median, 25th percentile, and minimum number of transfusions (logarithmic scale).

Table 3. Number of blood transfusions by age group and red blood cell alloimmunization among 620 patients with sickle cell disease.

\begin{tabular}{|c|c|c|c|c|c|}
\hline \multirow[t]{2}{*}{$\begin{array}{l}\text { Age group } \\
\text { (years) }\end{array}$} & \multirow[t]{2}{*}{$\begin{array}{c}\text { Number of } \\
\text { patients }\end{array}$} & \multicolumn{2}{|c|}{$\begin{array}{l}\text { Positive tests for } \\
\text { alloimmunization }\end{array}$} & \multicolumn{2}{|c|}{$\begin{array}{l}\text { Number of } \\
\text { transfusions }\end{array}$} \\
\hline & & $N$ & $\%$ & Median & Range \\
\hline 0 to 9.9 & 254 & 12 & 4.7 & 3 & $1-140$ \\
\hline 10 to 19.9 & 170 & 15 & 8.8 & 4 & $1-178$ \\
\hline 20 to 29.9 & 100 & 17 & 17.0 & 5 & $1-111$ \\
\hline 30 or more & 96 & 13 & 13.5 & 5.5 & $1-110$ \\
\hline
\end{tabular}

Table 4. Frequency of alloimmunization for patients younger or older than 14 years according to gender and type of sickle cell disease.

\begin{tabular}{|c|c|c|c|c|}
\hline & \multicolumn{2}{|c|}{$\begin{array}{l}\text { Patients under } 14 \text { years } \\
\text { of age }(N=333)\end{array}$} & \multicolumn{2}{|c|}{$\begin{array}{c}\text { Patients above } \\
14 \text { years of age }(N=275)\end{array}$} \\
\hline & Male & Female & Male & Female \\
\hline $\mathrm{Hb}$ SS patients & $6.6 \%(11 / 167)$ & $4.8 \%(6 / 125)$ & $9 \% \quad(9 / 100)$ & $13.7 \%(14 / 102)$ \\
\hline $\mathrm{Hb}$ SC patients & $0 \%(0 / 22)$ & $0 \%(0 / 19)$ & $14.8 \%(4 / 27)$ & $26.1 \% \quad(12 / 46)$ \\
\hline
\end{tabular}

The analysis was performed only for 608 hemoglobin $(\mathrm{Hb})$ SS or SC patients for whom the accurate number of blood transfusion was known. 
(58.2\%) had received blood transfusions. This transfusion rate among SCD patients is similar to those reported in other studies $(3,15,23)$.

The rate of alloimmunization observed in the present study was $9.9 \%$. Other studies have reported frequencies ranging from 2.6 to $47 \%(3,9-13,15-17,19,20,24)$. Studies presenting lower rates of alloimmunization (7.8 (8) and 6.0\% (14)) included patients who were predominantly in the pediatric group. In Brazil, rates of 12.9 (15), 20.8 (16), and $3.2 \%$ (24) have been reported. Again the lowest figure corresponds to a population of $83.9 \%$ of children aged less than 15 years. In the present study, 403/828 patients were less than 15 years old.

The relatively low rate found in the present study may have been influenced by several factors. Patients were not monitored for RBC antibodies after each transfusion and hence transitory antibodies were probably not detected. Antibody screening was performed employing the tube method up to July 1991 and then replaced by gel centrifugation. Hence, antibodies present at low titers were probably not detected during that period.

Another factor that could contribute to the low frequency found in the present study may be the high phenotypic compatibility between patients and blood donors. Further studies are necessary to confirm the influence of this factor on the frequency of alloimmunization. In Brazil, only one study (15) compared RBC phenotype between blood donors and patients with SCD. A higher frequency of $\mathrm{C}$ antigen in donors was reported $(66.7 \%$ compared with $46.0 \%$ in patients; $\mathrm{P}<0.01$ ), but no difference was detected for other RBC antigens, thus demonstrating high compatibility between donors and patients with SCD in the study.

The specificities of the antibodies found in the present study are similar to those found in other reports of alloimmunization in SCD. This is certainly due to the high immunogenicity of antigens C, D, E, and $\mathrm{K}(22)$, and also to the fact that RBC matching was not routinely employed for all of these antigens, except for antigen D.

Of the 124 alloantibodies identified, $8.9 \%$ were anti-D (7 associated and 4 isolated), a figure higher than reported in most international studies (8,11). A Brazilian study (15) reported $20 \%$ anti-D antibody among a total of 15 alloantibodies detected. The comparatively high frequency of anti-D antibodies found in the present study may be attributed to several factors. Since the obstetric history of the patients was not always available in their medical files, secondary alloimmunization related to pregnancy is to be considered. Many patients had been transfused before they were admitted to Hemominas Foundation and even after that, many were transfused in small hospitals in which blood transfusion is not adequately supervised.

Although alloimmunization is more frequent in females, in the present multivariate analysis gender was not a risk factor for alloimmunization $(\mathrm{P}=0.29)$, similarly to data reported by others $(3,25)$. Some investigators have reported a higher risk for females $(19,21)$.

Older patients were at a higher risk to develop alloimmunization, even after controlling for other significant variables. In another study (3), the rate of alloimmunization in patients younger than 10 years was lower than in other age groups, even after adjusting for the number of transfusions, with similar results observed by others $(8,14$, 26). Decreased immunologic response to antigens, lower frequency of blood transfusions and impossibility of pregnancy are factors that probably justify the low rate of alloimmunization in the pediatric group (9).

In the present study, the risk of developing alloimmunization was associated with the number of transfusions received, in agreement with the literature $(3,8,9,11,21)$. In the multivariate analysis, this variable remained statistically significant both in patients younger and older than 14 years of age. 
A significant association between $\mathrm{Hb}$ phenotype and alloimmunization was observed even after multivariate adjustment in patients older than 14 years. Patients with $\mathrm{Hb}$ SC presented a risk of alloimmunization almost three times as high as that for patients with $\mathrm{Hb} \mathrm{SS}$, an association hitherto unreported. In the Cooperative Study of Sickle Cell Disease (3) such association was not found, and a rather lower rate of alloimmunization was observed in patients with $\mathrm{Hb} \mathrm{SC}$ phenotype. This was attributed to a lower number of transfusions received by that group, as also observed by others $(20,21)$. In the present study, the association between $\mathrm{Hb}$ SC phenotype and alloimmunization was observed only for patients older than 14 years. For those below this cut-off point alloimmunization frequency was higher for SS children, although not statistically significant. Patients older than 14 years with $\mathrm{Hb} \mathrm{SC}$ disease received significantly fewer blood transfusions than those with the SS type. The number of transfusions for male and female patients was closely similar. Two non-excluding hypotheses for explaining the double positive gradient shown in Table 4 for patients above 14 years of age are possible: 1 ) older female patients and especially those with $\mathrm{Hb} \mathrm{SC}$ disease developed alloimmunization at a higher frequency because previous pregnancy and not blood transfusion was an induction factor. Menarche occurs significantly earlier in $\mathrm{Hb}$ SC than SS patients (27). Additionally, sexual activity, which is lower among SCD females compared with controls (28) may be higher for $\mathrm{Hb} \mathrm{SC}$ than for
SS females because their clinical status is usually better; 2) it is conceivable that there is a span of many years before the first transfusion is needed for $\mathrm{Hb} \mathrm{SC}$ male or female patients. Wayne et al. (2) suggested that alloimmunization in patients with thalassemia may occur more frequently if the blood transfusion is administered intermittently and started after childhood. Since patients with $\mathrm{Hb} \mathrm{SC}$ are faced with this situation, it is possible that a similar mechanism underlies the phenomenon observed in the present investigation.

Based on the present results and on literature data (3,6,11-14,29), RBC should be matched for $\mathrm{C}, \mathrm{E}$ and $\mathrm{K}$ antigens in transfusions administered to patients with hemoglobinopathies. The relevant roles of patient age and number of administered transfusions in the risk of alloimmunization were confirmed. In contrast to the international literature, older patients with $\mathrm{Hb}$ SC disease - and especially females - were at a higher risk to develop RBC alloimmunization, requiring further studies for verification and explanation of the observed phenomenon. Cohort studies based on neonatal screening and careful prospective obstetric data would be very helpful.

\section{Acknowledgments}

We gratefully acknowledge the contributions of ours colleagues at Hemominas Foundation and in the Hematology Division, University Hospital, Federal University of Minas Gerais, Belo Horizonte, MG, Brazil.

\section{References}

1. Zago MA (2001). Anemia falciforme e doença falciforme. In: Manual de Doenças mais Importantes, Por Razões Étnicas, na População Afro-Descendente. Secretary of Health Policy, Ministry of Health, Brasília, DF, Brazil.

2. Wayne AS, Kevy SV \& Nathan DG (1993). Transfusion management of sickle cell disease. Blood, 81: 1109-1123.

3. Rosse WF, Gallagher D, Kinney TR, Castro O, Dosik H, Moohr J,
Wang W \& Levy OS (1990). Cooperative Study of Sickle Cell Disease. Transfusion and alloimmunization in sickle cell disease. Blood, 76: 1431-1437.

4. Vichinsky EP, Haberkern CM, Neumayr L, Earles NA, Black D, Koshy M, Pegelow C, Abboud M, Ohene-Frempong K \& lyer RV (1995). A comparison of conservative and aggressive transfusion regimens in the perioperative management of sickle cell disease. 
The preoperative transfusion in Sickle Cell Disease Study Group. New England Journal of Medicine, 333: 206-213.

5. Davies SC \& Harewood MR (1997). Blood transfusion in sickle cell disease. Blood Reviews, 11: 57-71.

6. Vichinsky EP (2001). Current issues with blood transfusion in sickle cell disease. Seminars in Hematology, 38 (Suppl): 14-22.

7. Vichinsky EP, Luban NLC, Wright E, Olivieri N, Driscoll C, Pegelow $\mathrm{CH}$, Adams RJ \& Stroke Prevention Trail in Sickle Cell Anemia (2001). Prospective RBC phenotype matching in a stroke-prevention trial in sickle cell anemia: a multicenter transfusion trial. Transfusion, 41: 1086-1092.

8. Sarnaik S, Schornack J \& Lusher JM (1986). The incidence of development of irregular red cell antibodies in patients with sickle cell anemia. Transfusion, 26: 249-252.

9. Cox JV, Steane E, Cunningham G \& Frenkel EP (1988). Risk of alloimmunization and delayed hemolytic transfusion reactions in patients with sickle cell disease. Archives of Internal Medicine, 148: $2485-2489$.

10. Luban NLC (1989). Variability in rates of alloimmunization in different groups of children with sickle cell disease: effect of ethnic background. American Journal of Pediatric Hematology/Oncology, 11: 314-319.

11. Vichinsky EP, Earles APNP, Johnson RA, Hoag MS, Williams A \& Lubin B (1990). Alloimmunization in sickle cell anemia and transfusion of racially unmatched blood. New England Journal of Medicine, 322: 1617-1621.

12. Tahhan HR, Holbrook CT, Braddy LR, Brewer LD \& Christie JD (1994). Antigen-matched donor blood in the transfusion management of patients with sickle cell disease. Transfusion, 34: 562-569.

13. Norol F, Nadjahi J, Bachir D, Desaint C, Bataille MG, Beaujean F, Bierling P, Bonin P, Galacteros F \& Duedari N (1994). Transfusion and alloimmunization in sickle cell anemia patients. Transfusion Clinique et Biologique, 1: 27-34.

14. Hmida S, Mojaat N, Maamar M, Bejaoui M, Mediouni M \& Boukef K (1994). Red cell alloantibodies in patients with hemoglobinopathies. Nouvelle Revue Française d'Hématologie, 36: 363-366.

15. Moreira JG, Bordin JO, Kuroda A \& Kerbauy J (1996). Red blood cell alloimmunization in sickle cell disease: the influence of racial and antigenic pattern differences between donors and recipients in Brazil. American Journal of Hematology, 52: 197-200.

16. Fabron Junior A (2000). Estudo da significância clínica de aloanticorpos eritrocitários em pacientes com anemia falciforme. Doctoral thesis, Escola Paulista de Medicina, UNIFESP, São Paulo,
SP, Brazil.

17. Olujohungbe A, Hambleton I, Stephens L, Serjeant B \& Serjeant G (2001). Red cell antibodies in patients with homozygous sickle cell disease: a comparison of patients in Jamaica and the United Kingdom. British Journal of Haematology, 113: 661-665.

18. Fabron Junior A, Moreira JG \& Bordin JO (1999). Delayed hemolytic transfusion reaction presenting as a painful crisis in a patient with sickle cell anemia. São Paulo Medical Journal, 117: 38-39.

19. Orlina AR, Unger PJ \& Koshy M (1978). Post-transfusion alloimmunization in patients with sickle cell disease. American Journal of Hematology, 5: 101-106.

20. Oliva PG, Otero PB, Villalonga CG, Veranes MB, Aldama LO \& Echevarria MG (1985). Aloimunización en pacientes con enfermedad por hemoglobina S politransfundidos. Sangre, 30: 406410.

21. Reisner EG, Kostyu DD, Phillips G, Walker C \& Dawson V (1987). Alloantibody responses in multiply transfused sickle cell patients. Tissue Antigens, 30: 161-166.

22. Mollison PL, Engelfriet CP \& Contreras M (1997). Blood Transfusion in Clinical Medicine. 10th edn. Blackwell Science, Oxford, UK.

23. Thame JR, Hambleton IR \& Searjeant GR (2001). RBC transfusion in sickle cell anemia ( $\mathrm{HbSS}$ ): experience from the Jamaican Cohort Study. Transfusion, 41: 596-601.

24. Andrade SR, Brito GD, Calado NB, Marcos CPM, Serafim ESSM \& Rodrigues S (1999). Red blood cell alloimmunization in patients with sickle cell anemia. Revista Brasileira de Análises Clínicas, 31: 195-197.

25. American Association of Blood Banks (AABB) (1999). Technical Manual. 13th edn. AABB, Bethesda, MD, USA.

26. Spanos T, Karageorga M, Ladis V, Peristeri J, Hatziliami A \& Kattamis C (1990). Red cell alloantibodies in patients with thalassaemia. Vox Sanguinis, 58: 50-55.

27. Serjeant GR, Singhal A \& Hambleton IR (2001). Sickle cell disease and age at menarche in Jamaican girls: observations from a cohort study. Archives of Disease in Childhood, 85: 375-378.

28. Samuels-Reid JH, Scott RB \& Brown WE (1984). Contraceptive practices and reproductive patterns in sickle cell disease. Journal of the National Medical Association, 76: 879-883.

29. Castro O, Sandler SG, Houston-Yu P \& Rana S (2002). Predicting the effect of transfusing only phenotype-matched RBCs to patients with sickle cell disease: theoretical and practical implications. Transfusion, 42: 684-690. 